\title{
Assay of Some Biological Attributes Of Schistosome Snail Hosts and Schistosomiasis Transmission in Taraba North Senatorial District Nigeria
}

\author{
*Agere Hemen ${ }^{1}$,Kela,S.L ${ }^{2}$ and Istifanus, W.A ${ }^{2}$ \\ ${ }^{1}$ Biological Sciences Department, Federal University Wukari,Taraba State;Nigeria \\ ${ }^{2}$ Biological Sciences Department, Abubakar Tafawa Balewa University,Bauchi; Nigeria
}

\begin{abstract}
Snail study was conducted in Jalingo and Ardokola LGAS of Taraba North Senatorial district; for one year,from April to March.The survey was aimed at establishing the presence of Schistosome snail hosts and some of their life attributes that enhance the transmission of schistosomiasis in the area. Two sites in Ardokola and three sites in Jalingo were used for the investigations on snail occurrence, monthly density and infection rate,fecundity, hatching rates and mortality rates of the snail hosts. Bulinus forskalii, Bulinus (Physopsis) globosus, and Biomphalaria pfeifferi were the schistosome snail hosts collected. All the snails collected shedded cercariae. A significant difference $(P<0.05)$ was observed between infected and uninfected snail populations in the two areas studied. The egg-laying and hatching attributes of B.forskalii, B(P)globosus and B.pfeifferi showed significant difference $(P<0.05)$, however, there was no significant difference $(P>0.01)$ in the death rates of the three snail types. The high fecundity and reduced death rates of the schistosome snails, in addition to their high infection rates; predispose them for effective transmission of schistosomiasis in Taraba North Senatorial District. This demands an urgent snail control intervention to forestall the disease attaining epidemic status.
\end{abstract}

Key Words: Schistosome-Snail Host, Fecundity, Egg-hatching rates, Snail mortality, Schistosomiasis, Transmission.

\section{Introduction:}

Schistosomiasis is the second most important disease in the tropical regions of Southeast Asia, Africa and South America(WHO,1991).The Global Health Body further stated that, Schistosomiasis has never been common in temperate climates, but it affects 200 million persons worldwide of whom approximately $20 \%$ are at least partly disabled by the disease. $\mathrm{WHO}(1991)$ also warns that an estimated 500 to 600 million globally are at risk from the disease.

The role of intermediate hosts in the transmission of parasitic diseases is overwhelming. In the case of schistosomiasis certain gastropod snails have been implicated. The presence of snail hosts alone is not enough for transmission to occur except the snails are naturally infected with the trematode before transmitting unto the definitive host. Webbe(1962) and Chu(1978) held the view that when snail populations are high, number of infected snails also increases in direct proportion, hence greater transmission. Baalawy and Moyo(1970) and Udonsi(1990) however, argued that snail infection rates do not just increase because of mere increase in gross snail population, but depend on many factors such as; nature and accessibility of the habitat to the infected population. Udonsi(1990) further explained that at the end of hot season, not only is there a concentration of snails but increased human water contact as dry season advances and water becomes more scarce. In this condition, there is an increase in infection rates of the snails and possibly increased risk in terms of human exposure to the infection.

Although, chemotherapy is currently the bedrock of schistosomiasis control; there are a number of setbacks with some of the schistosomicides as reviewed by Kela and Bowen(1995). These include problem of resistance, availability and affordability by patients. According to McCullough(1992), mollusciciding is also a rapid way of bringing schistosomiasis transmission below the economic injury level. He explained that when chemotherapy is used alone, the reservoir hosts continue to contaminate water with schistosome eggs. He concluded that moreover, the snail is a weak link in the lifecycle, hence much easier to intercept transmission at this stage.

This investigation attempts to demonstrate that biological attributes of some schistosome snail hosts can enhance schistosomiasis transmission in an area. 


\section{Study Area:}

\section{Methodology:}

The study was limited to Taraba North Senatorial District; which comprises of Jalingo, Ardokola, Yorro, Zing ,Lau and Karim-Lamido Lgas. Jalingo and Ardokola were chosen for the study because of their overwhelming socioeconomic status in the zone(ref.Fig.1).

Fig. 2 shows that Jalingo is located between latitudes $11^{*} 00^{\prime}$ and $11^{*} 35^{\prime}$ east. It is bounded on the Northwest, South and Southwest by Ardokola; east by Yorro and North by Lau LGA. Jalingo LGA has a population of 139,845(2006 census). Jalingo town doubles as Local government and State headquarters. Ardokola LGA shown in Fig. 3 is located between latitudes $8 * 35^{\prime}$ and $9 * 00$ ' north and longitudes $11^{*} 00^{\prime}$ and $11^{*} 40^{\prime}$ east. It is bounded in the west by river Benue, east by Yorro LGA , northeast by Jalingo and south by Bali LGA. Sunkani is the headquarters of the LGA. Ardokola has a population of 86,921(2006 census).

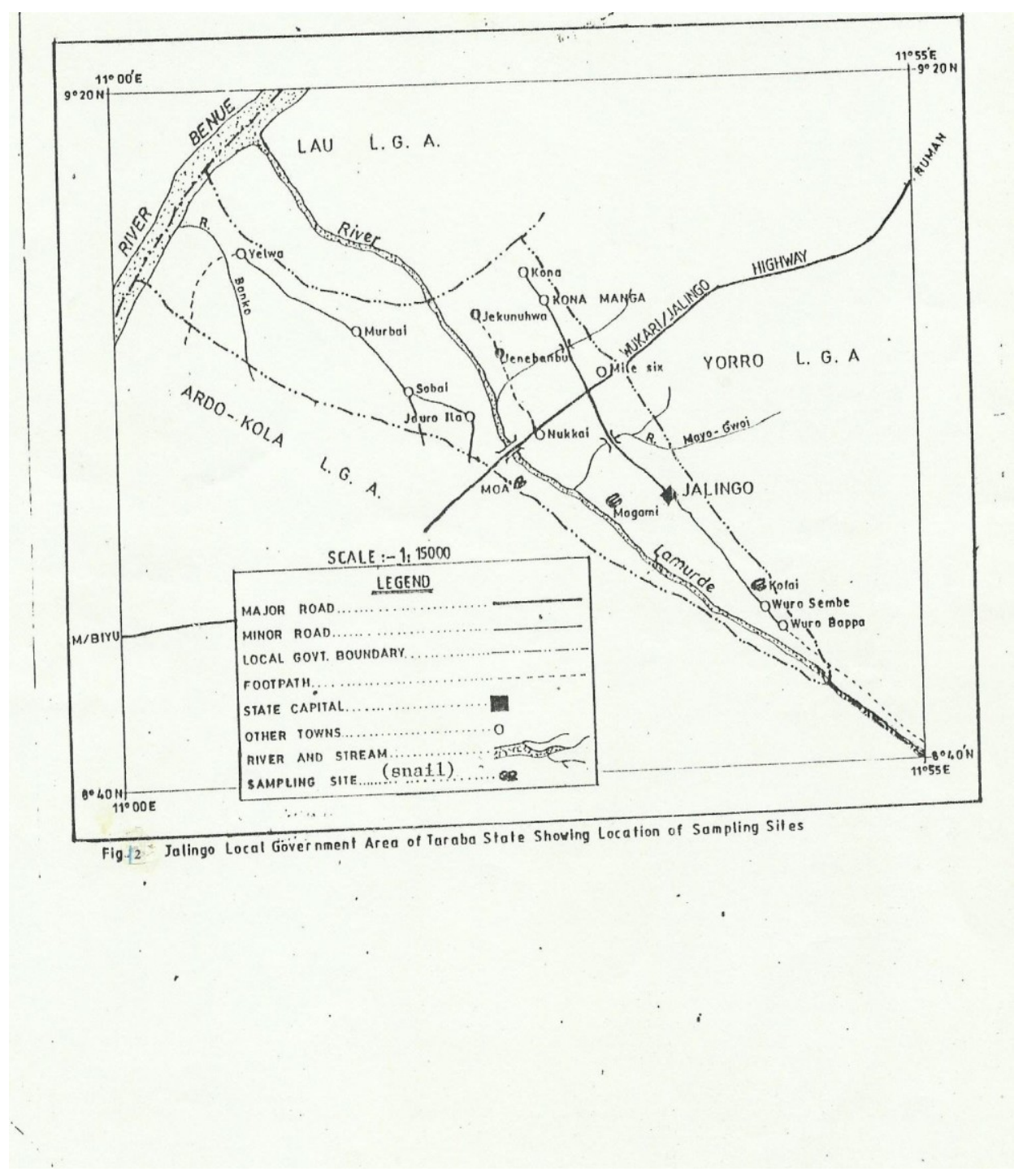




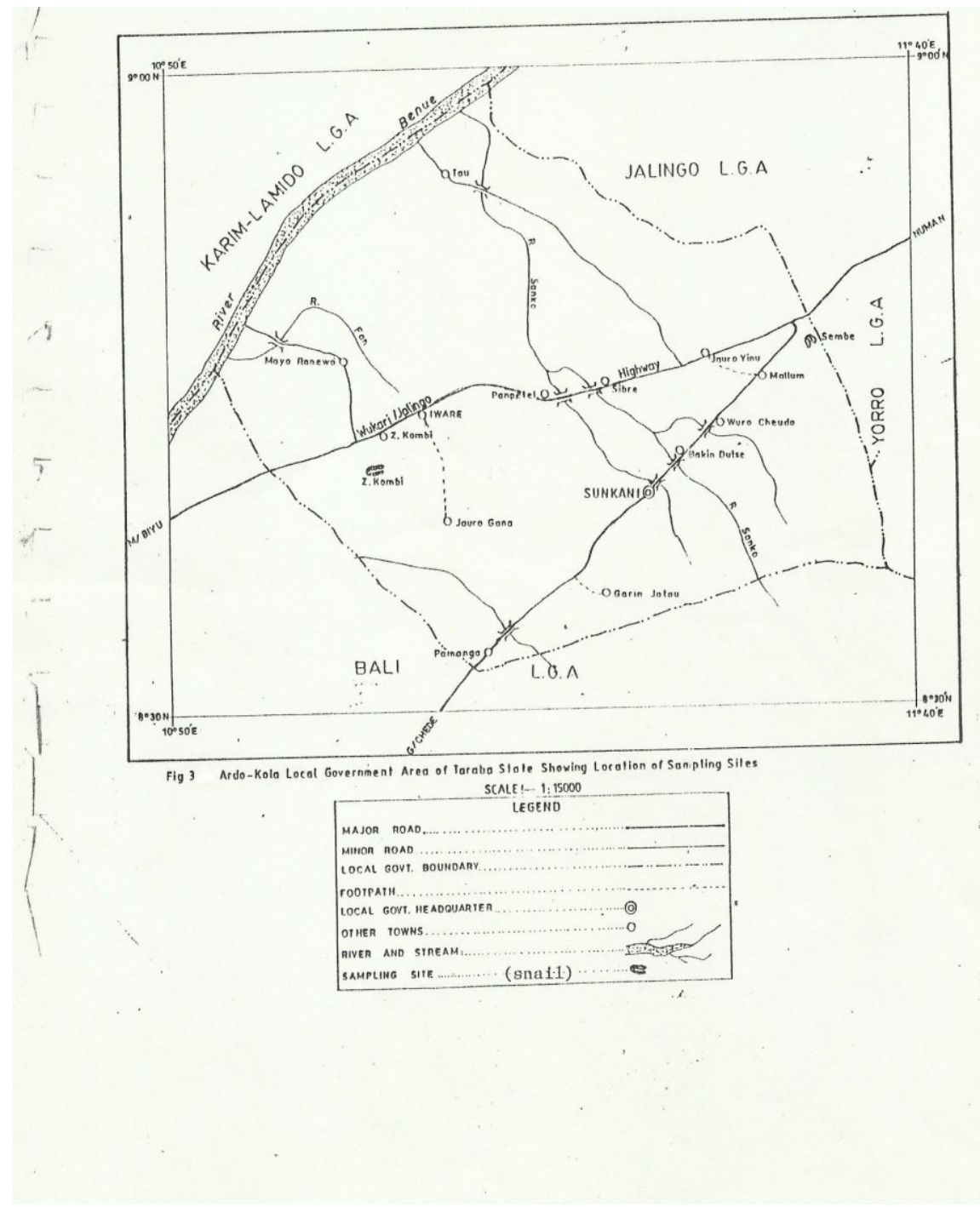

\section{Estimation of Snail Occurrence and Monthly Snail Populations:}

An initial survey of the gastropod fauna to determine snail occurrence was carried out for three months(April-June), in Ardokola and Jalingo lgas. Ponds, streams and rivers were the water bodies surveyed. Long-handle scoop nets of mesh $1.5 \mathrm{~mm}$ were used. The duration of collection was $15 \mathrm{mins}$ per site and the exercise was done weekly. All the snails collected were identified using the standard keys of Brown(1994).

For the monthly snail populations, sampling was done forth-nightly for one year; at 3 sites in Jalingo and 2 sites in Ardokola(April to March) at points where human contact was most identified. To determine the infection rate of the snails, all the snails collected were screened for shedding of cercariae after Christensen and Fradsen(1985).

\section{Egg-laying Rates:}

This attribute was investigated in Bulinus forskalii, Bulinus(Physopsis)globosus and Biomphalari pfeifferi for one month in the laboratory. Ten representatives of each of the snail species of the same morphology and state of maturity were placed in separate aquaria and observed weekly for one month. For each batch of snail species, two replicates were used. The number of eggs laid per week for each species was recorded.

\section{Hatching/Birth Rates:}

This biological attribute was also examined in the three schistosome hosts in the laboratory. Ten snails from each of the three schistosome snail types were placed separately in small aquaria containing clean tap water. Grounded lettuce leaves and other aquatic plants were put inside to serve as food and for anchorage. Mature snails of the size range $5-7 \mathrm{~mm}$ were used. After one week, the aquaria were examined for egg masses. Any aquarium with more than ten egg masses, had the batch of snails removed and returned to their natural 
habitats. After one week from the time of removal of snails, aquaria which had these snails were observed for one week for juvenile snails. The total daily number of eggs that hatched from all the egg masses for each of the snail species gave the birth rate of the species per day. This was done after the method described by McCullough(1962).

\section{Death Rates:}

Using a modified version of the method used by Woolhouse and Chandiwana(1990), the death rates of B.forskalii, B(P)globosus and B.pfeifferi were studied.2.5litre capacity cylindrical cages, each having a nylon mesh of $1.5 \mathrm{~mm}$ on wooden frame were used. Strips of plastic sheets were lined on both sides of the cylinder. Twenty snails from each of the three snail types were separately placed in different cages before each of the setups was kept into the snails natural habitats. Each cage was observed weekly for six months for the number of dead snails per month for the three snail types.

\section{Results:}

Table 1. Occurrence of Snail Species in Water bodies in Jalingo and Ardokola LGAS

\begin{tabular}{|c|c|c|c|c|c|c|c|c|c|}
\hline \multirow{2}{*}{$\begin{array}{l}\text { Snail } \\
\text { Species }\end{array}$} & \multicolumn{2}{|c|}{ Jalingo LGA } & \multirow[b]{2}{*}{$\begin{array}{c}\text { Stream } \\
\mathrm{n}=6\end{array}$} & \multirow[b]{2}{*}{$\begin{array}{l}\text { River } \\
\mathrm{n}=3\end{array}$} & \multirow[b]{2}{*}{$\begin{array}{l}\text { Total } \\
\quad \mathrm{n}=20\end{array}$} & \multicolumn{4}{|c|}{ Ardokola LGA } \\
\hline & $\begin{array}{c}\text { Ditch } \\
n=3\end{array}$ & $\begin{array}{l}\text { Pond/Dam } \\
n=9\end{array}$ & & & & $\begin{array}{r}\text { Pond/Dam } \\
n=15\end{array}$ & $\begin{array}{l}\text { Stream } \\
\mathrm{n}=5\end{array}$ & ${ }_{n}^{2}=4$ & $\begin{array}{l}\text { Total } \\
n=24\end{array}$ \\
\hline Bulinus forskalii & 1 & 4 & 1 & 1 & 7 & 3 & 2 & 1 & 6 \\
\hline $\begin{array}{l}\text { Bulinus(Physopsis) } \\
\text { globosus }\end{array}$ & 0 & 0 & 1 & 0 & 1 & 4 & 0 & 1 & 5 \\
\hline $\begin{array}{l}\text { Biomphalaria } \\
\text { Pfeifferi }\end{array}$ & 0 & 1 & 1 & 0 & 2 & 2 & 1 & 0 & 3 \\
\hline $\begin{array}{l}\text { Total } \\
\text { Percentage } \\
\end{array}$ & $\begin{array}{c}1 \\
(33.3) \\
\end{array}$ & $\begin{array}{c}5 \\
(55.6) \\
\end{array}$ & $\begin{array}{r}3 \\
(50)^{3} \\
\end{array}$ & $\begin{array}{r}1 \\
(50) \\
\end{array}$ & $\begin{array}{r}10 \\
(50) \\
\end{array}$ & $\begin{array}{r}9 \\
(60) \\
\end{array}$ & $\begin{array}{r}3 \\
(60)^{3} \\
\end{array}$ & $\begin{array}{c}{ }^{2} \\
(50)^{2} \\
\end{array}$ & $\begin{array}{c}14 \\
(58.3) \\
\end{array}$ \\
\hline
\end{tabular}

Numbers in parenthesis are percentages of habitats with snail, $\mathrm{n}=$ Number of habitats examined.

Table .1 shows that B.forskalii was present in all the water bodies surveyed in the two LGAS; whereas $\mathrm{B}(\mathrm{P})$ globosus was found to be more widely distributed in Ardokola LGA than Jalingo LGA. The Monthly Snail populations for the two LGAS are shown in table 2.

\begin{tabular}{|c|c|c|c|c|c|c|c|c|}
\hline \multirow{3}{*}{$\frac{\text { Month }}{\text { April }}$} & \multirow{3}{*}{$\frac{\text { B.forsk }}{34(14)}$} & \multicolumn{3}{|l|}{ Jalingo LGA } & \multirow{2}{*}{ B.forsk } & \multicolumn{3}{|c|}{ Ardokola LGA } \\
\hline & & $\mathrm{B}(\mathrm{p})$ glob $\mathrm{B}$ & B.pf & Cotal & & $\mathrm{B}(\mathrm{P})$ glob & B.pf & Total \\
\hline & & $185(80)$ & $29(3) \quad 2$ & $248(97)$ & $32(13)$ & $13(5)$ & $28(4)$ & $73(22)$ \\
\hline May & $9(4)$ & 222(94) & $31(5) 25$ & $52(103)$ & $13(5)$ & $5(2)$ & $8(0)$ & $26(7)$ \\
\hline June & $203(62)$ & $318(132)$ & ) $50(9) 5$ & $571(203)$ & $43(18)$ & $40(12)$ & $13(2) 96(32)$ & \\
\hline July & $58(18)$ & $108(41)$ & $36(4)$ & $200(63)$ & $29(10)$ & $47(22)$ & $26(2)$ & $102(34)$ \\
\hline August & 26(9) & $35(11)$ & $24(5)$ & $85(25)$ & 11(3) & $43(15)$ & $24(2)$ & $78(20)$ \\
\hline September & $4(2)$ & $7(2)$ & $18(1)$ & $29(5)$ & $32(9)$ & $15(4)$ & $28(4)$ & $65(17)$ \\
\hline October & $2(0)$ & $5(0)$ & $10(0)$ & $17(0)$ & $9(2)$ & $23(5)$ & $19(1)$ & $51(8)$ \\
\hline November & 1(1) & $2(0)$ & $8(0)$ & 11(1) & $9(3)$ & $8(1)$ & $31(9)$ & $48(13)$ \\
\hline December & $4(1)$ & $9(2)$ & 13(1) & $26(4)$ & $5(2)$ & $9(2)$ & $24(3)$ & $38(7)$ \\
\hline January & $2(1)$ & $29(8)$ & $20(4)$ & $51(13)$ & $37(17)$ & $105(42)$ & $12(2)$ & $154(61)$ \\
\hline February & $10(3)$ & $4(0)$ & $45(12)$ & $59(15)$ & $12(5)$ & $44(18)$ & $21(4)$ & $77(27)$ \\
\hline March & $7(2)$ & $66(22)$ & $28(4)$ & 101(28) & 11(1) & $14(6)$ & $30(6)$ & $55(13)$ \\
\hline Tota & 360 & 990 & 212 & 1750 & 243 & 376 & 264 & 883 \\
\hline Infected no & 117 & 329 & 48 & 557 & 88 & 144 & 144 & 376 \\
\hline
\end{tabular}

B.forsk=Bulinus forskalii; $\quad$ B(P)globosus=Bulinus(Physopsis)globosus; $\quad$ B.pf=Biomphalaria pfeifferi. ( ) Figures in parenthesis are monthly infected snail populations.

From Table.2 $\mathrm{B}(\mathrm{P})$ globosus has the highest population density in the two areas (Jalingo990[56.6\%];Ardokola-376[42.6\%]).Table.2 also shows that $\mathrm{B}(\mathrm{P})$ globosus has the highest infection rate in Jalingo(329/990) and second highest in Ardokola(144/376) after B.pfeifferi(144/264).

The results of the investigations on some life attributes are shown in tables 3,4 and 5 below. 
Table.3: Egg-laying Rates of Three Schistosome Snail Hosts.

\begin{tabular}{llccc}
\hline Week & \multicolumn{2}{c}{ Snail Species/No.of Eggs } & Total \\
\hline 1 & $\mathrm{~B}(\mathrm{P})$ globosus & B.forskalii & B.pfeifferi & 99 \\
2 & 23 & 16 & 60 & 49 \\
3 & 16 & 10 & 23 & 27 \\
4 & 10 & 06 & 11 & 21 \\
\hline Total & 06 & 02 & 13 & 196 \\
Average & 55 & 34 & 107 & 49 \\
\hline
\end{tabular}

Table. 3 shows that all the snails laid eggs, though the number of eggs decreased progressively from week one to week four.Biomphalaria pfeifferi laid the highest number of eggs(107).

Table.4.Birth Rates Of Three Schistosome Snail Hosts:

\begin{tabular}{lcccc}
\hline Week & & Snail Species/Number of Eggs & & Total \\
\hline 1 & B(P)globosus & B.forskalii & B. pfeifferi & 77 \\
2 & 16 & 14 & 47 & 55 \\
3 & 19 & 10 & 26 & 32 \\
4 & 11 & 08 & 13 & 126 \\
5 & 38 & 42 & 46 & 137 \\
6 & 38 & 46 & 83 & 186 \\
7 & 46 & 59 & 90 & 204 \\
\hline Total & 52 & 62 & 356 & 817 \\
Average & 220 & 241 & 51 & 117 \\
\hline
\end{tabular}

Table. 4 shows an initial decrease in the hatching rate of the eggs the first three days, but an increase from day four to seven. Biomphalaria pfeifferi had the highest rate(356eggs) with Bulinus(Physopsis)globosus having the lowest hatching rate(220eggs).

Table.5:Death Rates Of Three Schistosome Snail Hosts

\begin{tabular}{|c|c|c|c|c|}
\hline \multirow[t]{2}{*}{ Month } & \multicolumn{3}{|c|}{ Snail Species/No.of Dead Snails } & \multirow[b]{2}{*}{$\begin{array}{l}\text { Total } \\
n=60\end{array}$} \\
\hline & $\begin{array}{l}B(P) \text { globosus } \\
n=20\end{array}$ & $\begin{array}{l}\text { B.forskalii } \\
n=20\end{array}$ & $\begin{array}{l}\text { B.pfeifferi } \\
n=20\end{array}$ & \\
\hline February & 4 & 4 & 1 & 9 \\
\hline March & 1 & 2 & 1 & 4 \\
\hline April & 1 & 4 & 1 & 6 \\
\hline May & 0 & 0 & 0 & 0 \\
\hline June & 0 & 2 & 0 & 2 \\
\hline July & 1 & 1 & 1 & 3 \\
\hline Total & $07(35 \%)$ & $13(65 \%)$ & $4(25 \%)$ & $24(40 \%)$ \\
\hline
\end{tabular}

$\mathrm{n}=$ number of snails per each species that were used in the experiment.

$\%=$ Percentage deaths per species in the six months of study

Table. 5 shows that more deaths occurred in the first three months than the last three months of the observation. B.forskalii showed the highest death rate $(65 \%)$; while B.pfeifferi had the lowest $(25 \%)$.

\section{Discussion:}

The occurrence of naturally infected Bulinus forskalii, Bulinus(physopsis)globosus and Biomphalaria pfeifferi in the water bodies surveyed in the two LGAS, and their persistent occurrence throughout the twelve months of the snail survey;strongly suggest an ongoing schistosomiasis transmission in the area studied. The shedding of cercariae by all the three types of Schistosome snail host points to the likely hood of occurrence of all forms of schistosomiasis in the area. The suitability of these three snail species as intermediate hosts of schistosomes has been reported by several authorities.Betterton(1988) reported Biomphalaria pfeifferi as the sole intermediate host of Schistosoma mansoni in Nigeria. Madson and Coulibaly(1990) reported that Bulinus(Physopsis)globosus is the major intermediate host for Schistosoma haematobium both in Nigeria and other parts of West Africa. By the works of Ndifon et.al(1988) Bulinus forskalii is an established intermediate host for Schistosoma bovis in West Africa.

The high oviposition rates, high hatchability and fairly low mortality rates shown by these three schistosome snail hosts, connote the suitability of the snails as intermediate hosts of disease parasites in the area studied.In addition, the low death rates of emerging juveniles imply that the snails can live long enough for the parasites to develop fully in them. This ability will definitely enhance effective transmission of the parasites.

Though chemotherapy is the current most laudable method of schistosomiasis control, It should be noted that when chemotherapy is used alone, the reservoir hosts continue to infest water bodies with 
schistosome eggs. More so that the snail is a weak link in the lifecycle it is much easier to obstruct transmission at this stage.

\section{Conclusion:}

For schistosomiasis to be effectively controlled, chemotherapy should always be used in conjunction with mollusciciding to obstruct the lifecycle at its weakest point. Reservoir hosts may continue to re-infest water bodies with schistosome eggs but there would be no suitable snails to enhance the completion of the lifecycle.

\section{References:}

[1]. Baalawy,S S and Moyo,H.G(1970). Studies on the Population Dynamics of Bulinus(Physopsis)nasutus and natural Schistosoma haematobium infection rates in relation to rainfall at Misunguri and Usagara, Mwanza. East.Afr.Med.J.47(9):472-478

[2]. Betterton,C.C(1984). Spatiotemporal distribution patterns of Bulinus rohsi, Bulinus forskalii and Bulinus Senegalensis in newly irrigated areas in Northern Nigeria. J.Mollusc.Studies.50:137-152.

[3]. Brown,D.S(1994).Fresh Water Snails of Africa and their Medical Importance. $2^{\text {nd }}$. Ed. Taylor and Francis Publishers, London.609pp.

[4]. Christensen,N.O and Fradsen,H(1985).An Introduction to the Taxonomy, Morphology, Biology and Transmission Ecology of species of the genus Schistosoma causing African Schistosomiasis.DBL.33pp.

[5]. Chu,K.Y(1978). Trials of Ecological and Chemical Measures for the Control of Schistosomiasis haematobium in a Volta Lake Village.Bull.Wld.Hlth.Org.56(2):313-322.

[6]. Coulibaly,G and Madsen,H(1990).Seasonal Density Fluctuations of Intermediate Hosts of Schistosomes in Two Streams in Bamako, Mali. J.Afr.Zool.104:202-212.

[7]. Kela,S.L and Bowen,I.D(1995).Control of Snails and Snail-borne diseases. Pesticide Outlook 6(1):22-27.

[8]. McCullough,F.S(1962).Further Observations on Bulinus(Bulinus)truncatus rohfsi(clessin) in Ghana: Seasonal Fluctuations andBiology.Bull.Wld.Hlth.Org.27:161-170.

[9]. McCullough,F.S(1992).The Role of Molluscicides in Schistosomiasis control.WHO//92.107:34pp.

[10]. Ndifon,G.T; Betterton,C.C; Bassey,S.E;Tan,R.M and Oyeyi,T(1988).Schistosomiasis in Kano State,Nigeria.1.Human Infections near Dam sites and the Distribution and Habitat Preferences of potential Snail Intermediate hosts. Ann.Trop.Med.Parasitol.86(6):561-570.

[11]. Udonsi,J.K(1990).Human Community Ecology of Urinary Schistosomiasis in relation to Snail vector Bionomics in the Igwun River Basin,Nigeria.Trop.Med.Parasitol.41:131-135.

[12]. WHO(1991. Tropical Diseases Progress in Research,1989-1990 .pp42-47.

[13]. Woolhouse,M.E.J and Chwandiwana,S.K(1990).Population Biology of the Freshwater Snail, Bulinus globosus in Zimbabwe High Veld. J.Appld.Ecol.27:41-59. 